\author{
井上 眞一・土屋 智則・尾之内 千夫・岡本 弘
}

\title{
Study on High Damping Rubbers, Part 1. Development of High Damping Rubbers by Structural Modification of Natural Rubber
}

\author{
Shin-ichi INOUE, Tomonori TSUCHIYA, Yukio ONOUCHI, Hiroshi OKAMOTO (Department \\ of Applied Chemistry, Aichi Institute of Technorogy, 1247 Yachigusa, Yakusa-cho, Toyota \\ 470-0392)
}

The High damping rubber for seismic bearing was developed by the structural modification, cis -trans isomerization, of natural rubber (NR). Dimethyl sulfoxide (DMSO), tetramethylene sulfoxide(TMSO), and tetramethylene sulfone, (TMSN) were used for modifiers. The isomerization rates of NR were compared by using the three modifiers. The isomerization rate was $\sim 19 \%$ in a whole amount for NR. The isomerization of NR gave a high hysteresis loss and lower compression set. The DMSO was more significant for the degree of an activity on the modifiers than that of TMSO and TMSN. Hysteresis loss of the isomeric rubber was about 2.0 times bigger than that of the control (NR), and the compression set of the isomeric rubber was smaller than that of the control. Vulcanization was also remarkably accelerated.

(Received on June 22, 1998)

Key Word: Natural rubber, Structural modification, Sulfoxide, Sulfone, High damping rubber, Hysteresis loss, Compression set, Vulcanization

\section{1. 緒言}

1995 年 1 月 17 日早朝に起きた阪神・淡路大震 災 (兵庫県南部地震)の莫大な被害のために，地震 対策への関心が高まり，なかでも建築の分野では 積層ゴムを利用した免震技術が注目されている。 この免震技術は道路，橋などを対象に土木の分野 でも利用されつつある。

薄いゴムと鉄板とを交互に積層した積層ゴム は，せん断方向にゴム本来の柔軟性を保ち，圧縮 方向の岡性を高める特徵をもち，設計にようては

†本報を「高減衰ゴム材料に関する研究 (第 1 報)」とする.
水平剛性の 1600 倍以上の鉛直剛性を得ることも 可能である.もう一つの特徵は, 振動エネルギー を吸収する減衰性をもつことで，建物と基礎との 相対変位を抑制する役割を果たすものである．通 常の積層ゴムでは減衰が小さく，他の減衰装置と の組み合わせが必要であるのに对して，最近減衰 性を兼備した高減衰積層ゴムの開発が進められて いる。しかし，減衰性を増加すると，圧縮永久U ずみも増加することが問題となっている.

現在免震ゴムとして天然ゴム $(\mathrm{NR})$ が用いられ ているのは硬度, 弾性特性などに優れている点, つまり圧縮永久Uずみが小さく, 諸物性の温度依 存性が小さいことにある。また，歴史的にみても 
何十年も建物の下に敷かれてきた，歴史の最も長 い，物性のはっきりした NRの実績からであろ

j. 高ヒステリシスロスが要求される免震用のゴ ム材料に低ヒステリシスロスの NRが用いられ ていることから，このままNRが普及していく とは考えにくいが，物性および価格を考慮する と，NRが免震用として望ましいことも事実であ る.

そこで，NRの極性を増加させずに部分的に構 造変性を行うことにより，構造規則性を乱し，結 晶化傾向を低下させ，分子間力の極めて低いジエ ン骨格構造の分子鎖屈曲性を活かしつつ，ゴムの 弾性を低下させ，粘性を高くすることにより，減 衰性が付与できるものと考之, 部分的構造変性と してNRのシス位からトランス位への異性化反 応を利用した ${ }^{1-3)}$. 異性化凨として，テトラメチ レンスルホン (TMSN), ジメチルスルホキシド (DMSO) およびテトラメチレンスルホキシド (TMSO)を用いて，NRの部分的な異性化によ る免震性についての検討を行った.

\section{2. 実験}

\section{1 試薬および供試ゴム}

原料ゴムには NR (SMR CV-60)を，配合剂に はカーボンブラック(東海カーボン株式会社製シ 一スト 600), ホワイトカーボン(徳山曹達株式会 社製トクシール GU)，ステアリン酸，酸化亜鉛\# 1 , 加硫促進剂 MBTS および硫黄 (大内新興化 学工業株式会社) を使用し, 異性化剂は TMSO [EP］(東京化成工業株式会社)，DMSO [GR] およびTMSN [GR]（ナカライテスク株式会 社）を市販品のまま使用した.

\section{2 構造変性 NR の調製および加硫}

NR 6 インチオープンロールを用いて，ロー ル温度 $50 \pm 2{ }^{\circ} \mathrm{C}$ ，ロール間隙 $0.4 \mathrm{~mm}$ で 5 分間 素練りしたのち， 3 分 30 秒間かけて異性化剂お よびカーボンブラックを添加し，ついで 1 分 30 秒間かけて各種ゴム用配合剂(Table 1)を混練り し， 3 分間かけて配合剂の分散を行い，1 分間か けてゴム試料シートを調製した。

上記の方法で構造変性した NR 配合ゴムを, $140^{\circ} \mathrm{C}$ で所定時間熱板プレスした。その際の最適 加硫時間は，キュラストメーターを用いて評価し た.
Table 1 Compouding recipe (phr).

\begin{tabular}{lc}
\hline NR(SMR CV-60) & 100 \\
Carbon black (Seast 600) & 20 \\
Stearic acid & 2 \\
Zinc oxide & 5 \\
MBTS(Dibenzothiazyl disulfide) & 1 \\
Sulfur & 2.5 \\
\hline
\end{tabular}

\section{3 加硫物の物性試験}

応力ーひずみ挙動およびヒステリシス挙動は, オリエンテック社製テンシロン RTA-100 型を用 いて行った。なお変形速度は $100 \mathrm{~mm} / \mathrm{min}$ とし， 測定は室温 $\left(23 \pm 2{ }^{\circ} \mathrm{C}\right)$ で行った。また試験片サン プルはJIS 3 号ダンベルを使用した。圧縮永久 ひずみは, JIS K $6301 に$ 従い $70^{\circ} \mathrm{C} て ゙ 22$ 時間処 理したのちの厚み変化を測定した。膨潤試験(試 料 寸法 $20 \mathrm{~mm} \times 5 \mathrm{~mm}$, 直径 $\phi 20 \mathrm{~mm}, 190$ $\mathrm{mm})$ はベンゼン溶媒中, 室温 $\left(23 \pm 2{ }^{\circ} \mathrm{C}\right)$ で行い, $\mathrm{NR}$ 加硫ゴムの比重は 0.96 , 試料中のゲルゴム の容積分率は $1.0 ， \mu$ 值には 0.44 を用いて Flory -Rehner 式より網目鎖密度を算出した。

\subsection{IR 測定}

日本分光社製 $F T / I R-5300$ 型を使用し, NEATおよびATR 法により測定した。ATR 法

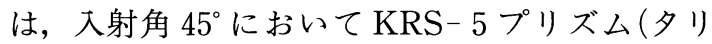
ウム系の混晶)を用いて測定した。吸収の補正は 行っていない.

\section{5 固体 ${ }^{13} \mathrm{C} N \mathrm{NMR}$ 測定}

固体 ${ }^{13} \mathrm{C} \quad \mathrm{NMR}$ 測定はVarian 社製 UNITY plus $300 \mathrm{MHz}$ の装置を用いた。 スピンー格子緩 和時間 $\left(\mathrm{T}_{1 \mathrm{C}}\right)$ はパルス系列で $180^{\circ}$ と $90^{\circ}$ パルスと の間の待機時間を $0.0001 \sim 2$ 秒と変化させ，室 温において回転速度 $2.5 \mathrm{kHz}$ で測定した(IR 法)。スピンースピン緩和時間 $\left(\mathrm{T}_{2 \mathrm{C}}\right)$ はパルス系列 でスピンエコー繰り返し時間を $0.0004 \sim 0.008$ 秒 と変化させ，室温において回転を与えずに測定を 行った (CPMG 法).

\section{3 . 結果および考察}

\section{1 スルホキシドおよびスルホンによる NR の異性化}

NRに対して，3 種類の異性化剂すべてが活性 を示し，なかでも TMSN は，NR 中の二重結合 を減少させることなく，19\%をトランス構造へ異 


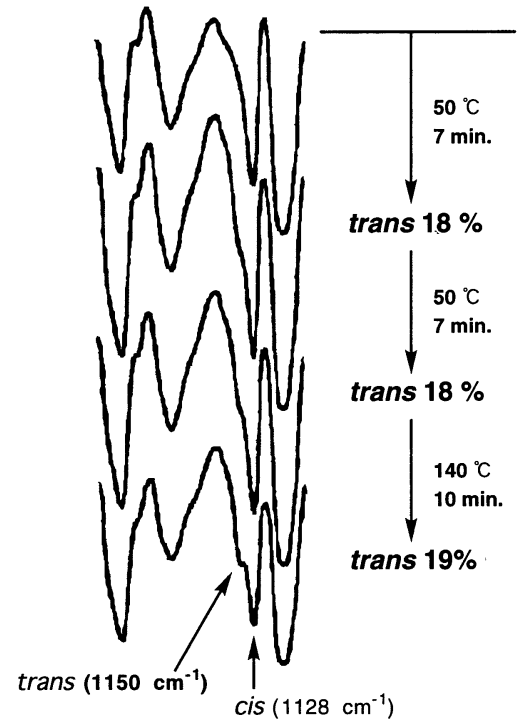

Fig. 1 Trans content of modified NR with TMSN by IR spectrum.
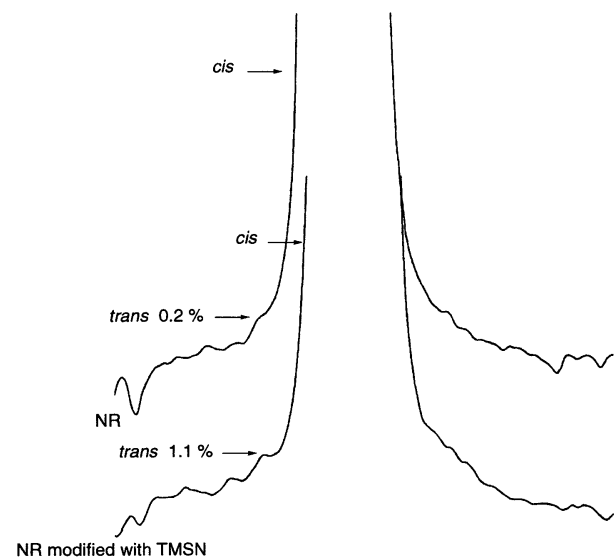

Fig. 2 Trans content of modified NR with TMSN by solid state ${ }^{13} \mathrm{C}$ NMR spectrum.

性化した，次いで実用配合の加硫ゴムでの異性化 率を求めることとし，TMSN を添加した NRの 加硫物の IR 測定を行い，トランス構造に起因す る $1150 \mathrm{~cm}^{-1}$ 吸収の発現は確認できた(Fig. 1 ).

TMSNを添加し加硫した構造変性 NRの固 体 ${ }^{13} \mathrm{C}$ NMR において， $\delta$ 值 $40 \mathrm{ppm}$ にトランス 構造に起因する吸収が発現し，その異性化率は約 1.1\%であった(Fig. 2)。このような異性化率の 低下は，硫黄および加硫促進剤(MBTS)などの

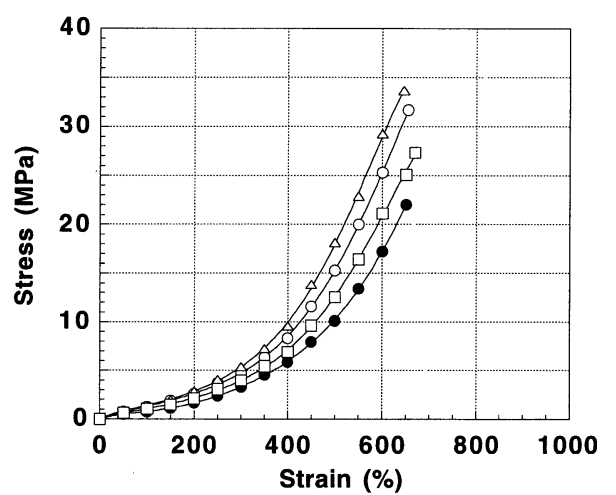

Fig. 3 Stress-strain curves of carbon black-loaded NR vulcanizates modified with sulfoxide and sulfone. Amount of modifier : $0.01 \mathrm{~mol}$.

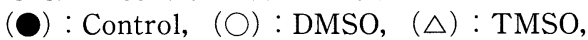
( $\square)$ : TMSN

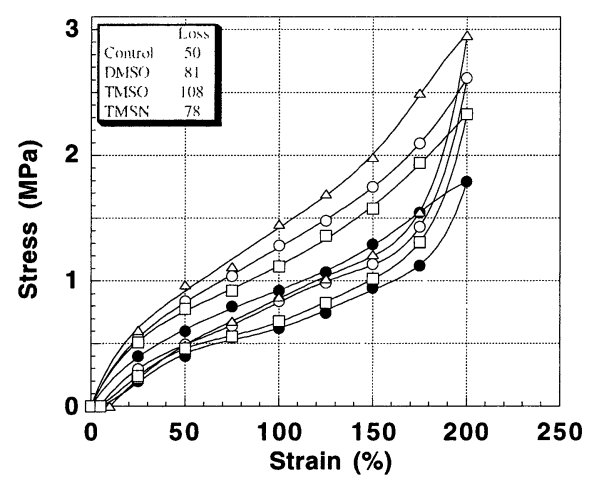

Fig. 4 Hysteresis loops of carbon black-loaded NR vulcanizates modified with sulfoxide and sulfone. Amount of modefier: $0.01 \mathrm{~mol}$.

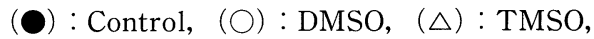
(口) : TMSN

影響と考えられることから，異性化剂の添加量に より異性化率を制御することは可能である.

\section{2 スルホキシドおよびスルホンによる構造 変性 NR の減衰性}

試薬ごとに官能基数が異なるため, 異性化剤の 量は, mol 表示とし, NR $(50 \mathrm{~g})$ に対して 0.01 mol とした．NRにそれぞれの異性化剂を添加す ると，著しく加硫速度が促進した。その度合は次 のようであった。

$\mathrm{NR}<\mathrm{NR}+\mathrm{TMSN}<\mathrm{NR}+\mathrm{DMSO}<\mathrm{NR}+$ TMSO

キュラストメーターの測定でトルク值が $100 \%$ 
Table 2 Physical properties of carbon black-loaded NR vulcanizates modified with sulfoxide and sulfone. Amount of modifier : $0.01 \mathrm{~mol}$.

\begin{tabular}{lcccc}
\hline & Control & DMSO & TMSO & TMSN \\
\hline Vulcanization time $(\mathrm{min})^{\text {a) }}$ & 32 & 18 & 16 & 19 \\
Compression set $(\%)^{\text {b) }}$ & 32 & 29 & 29 & 40 \\
Crosslinking density & 1.34 & 1.73 & 1.97 & 1.51 \\
$\times 10^{-4}\left(\mathrm{~mol} / \mathrm{cm}^{3}\right)$ & & & & \\
\hline
\end{tabular}

a) Torque 100 .

b) Condition : $22 \mathrm{~h}$ at $70^{\circ} \mathrm{C}$.

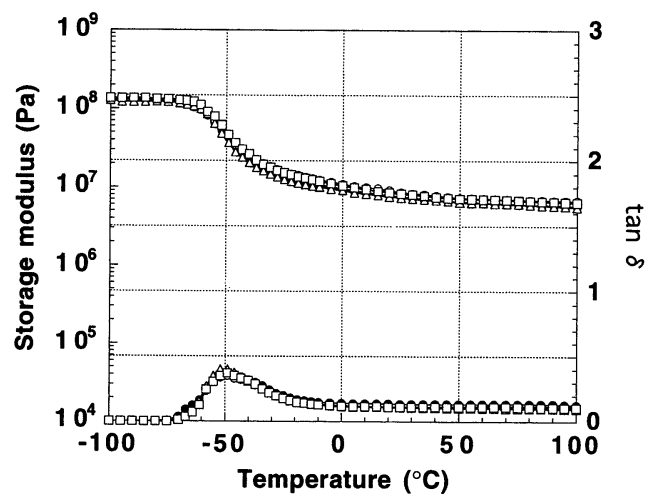

Fig. 5 Temperature dependence of storage modulus and loss tangent of carbon black-loaded NR vulcanizates modified with sulfur compounds. Amount of modifier : $0.01 \mathrm{~mol}$.

(O) : Control, (O) : $130^{\circ} \mathrm{C},(\triangle): 140^{\circ} \mathrm{C}$, (口) : $150^{\circ} \mathrm{C}$

となる時間(キュラスト T 100) まで加硫したゴム の応力ーひずみ挙動において，TMSNを添加す ると, 破断強度 $\left(\mathrm{T}_{\mathrm{B}}\right)$ および伸び $\left(\mathrm{E}_{\mathrm{B}}\right)$ は少し上昇 し，DMSO あるいは TMSO を添加すると， $\mathrm{E}_{\mathrm{B}}$ は少し上昇するだけであるが， $\mathrm{T}_{\mathrm{B}}$ は著しい上昇 を示した (Fig. 3 )。特に TMSOの場合， $\mathrm{T}_{\mathrm{B}}$ は コントロールと比較して $12 \mathrm{MPa} も$ 増加し， 34 $\mathrm{MPa}$ と高い值を示した。 変形率 $200 \%$ の ヒステ リシスループは TMSO で, NRの約 2 倍のロス を示した(Fig. 4 )。 また， ロス比率も同様の傾向 を示しており，最大值はコントロールのロス比率 の約 2.0 倍に近似した值を示す。圧縮永久ひずみ は，DMSO あるいは TMSO を添加すると約 3 \%減少したが，TMSN を添加すると約 8 \% 増加 し(Table 2)，これに比例して，膨潤試験による 網目鎖密度も増加した。
貯蔵弾性率の温度依存性をみる と異性化によるモジュラスの変化 はみられず, $\tan \delta$ の温度依存性 も， $-50^{\circ} \mathrm{C}$ 付近に $\mathrm{T}_{\mathrm{g}}$ に起因する ピークはみられるが，異性化によ る変化はみられない(Fig. 5$)$.

以上述べてきたように，スルホ ンおよびスルホキシドによる NR の部分的な異性化は，七ステリシ スロスを増加させ，NR へ減衰性 を付与するとともに，従来ゴム工 業で解決が困難とされていたヒステリシスロスが 増加すれば，圧縮永久ひずみも増加するという定 説をくつがえし，二律背反性を切り開くことが可 能となった。

\subsection{DMSO を添加した構造変性 NR の減衰性}

実用性(特にコスト面)を考えると，DMSO が 最も優れた異性化剤であることから，ここでは DMSO を用い検討を行った。

3.3.1 加硫温度の影響 加硫温度を 130,140 および $150^{\circ} \mathrm{C}$ に設定し, 減衰性の評価を行った。 ロール温度は室温 $\left(23 \pm 2{ }^{\circ} \mathrm{C}\right)$ とし，DMSOの 添加量は $0.01 \mathrm{~mol}$ とした。

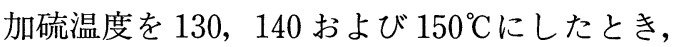
加硫温度の上昇に比例して, 加硫速度は著しく促 進した。キュラスト T 100 で加硫した応力ーUず み挙動において， $\mathrm{E}_{\mathrm{B}}$ は加硫温度に関係なくすべ て NR と同様の值を示すが, $\mathrm{T}_{\mathrm{B}}$ は加硫温度の低

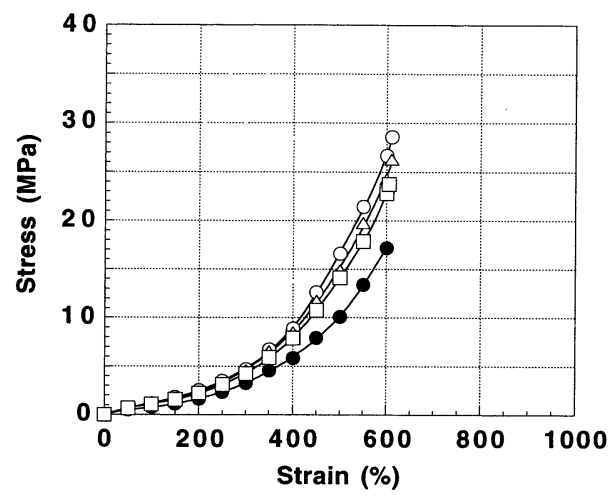

Fig. 6 Stress-strain curves of carbon black-loaded NR vulcanizates modified with DMSO. Amount of modifier : $0.01 \mathrm{~mol}$.

(O): Control, (O) : $130^{\circ} \mathrm{C},(\triangle): 140^{\circ} \mathrm{C}$, (口) : $150^{\circ} \mathrm{C}$ 


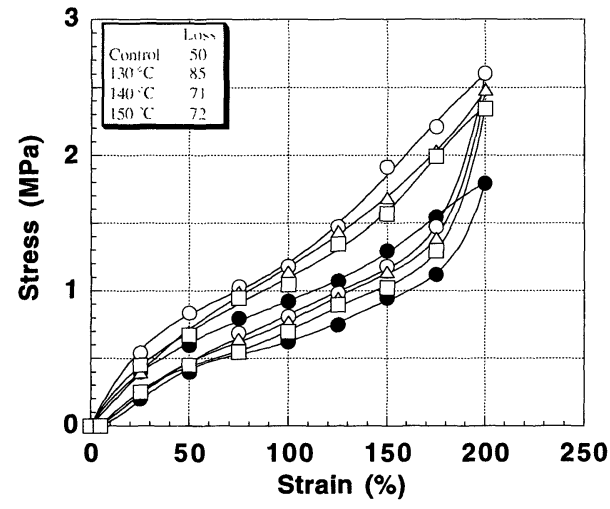

Fig. 7 Hysteresis loops of carbon blackloaded NR vulcanizates modified with DMSO. Amount of modifier : $0.01 \mathrm{~mol}$.

(O) : Control, $(\bigcirc): 130{ }^{\circ} \mathrm{C},(\triangle)$ : $140^{\circ} \mathrm{C},(\square): 150^{\circ} \mathrm{C}$

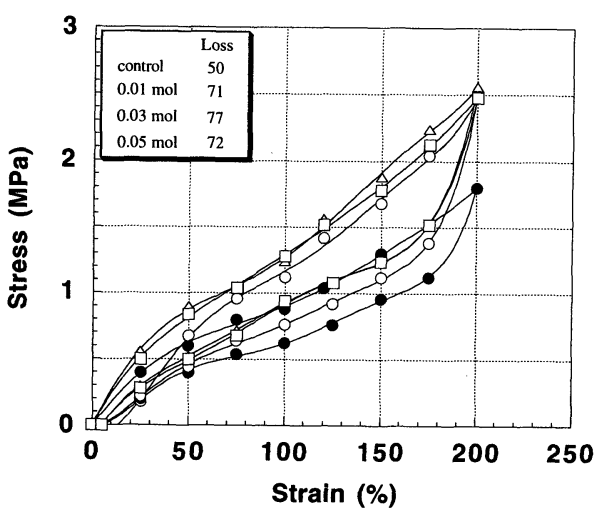

Fig. 8 Hysteresis loops of carbon blackloaded NR vulcanizates modified with DMSO.

(O) : Control, ( $\bigcirc): 0.01 \mathrm{~mol},(\triangle)$ : $0.03 \mathrm{~mol},(\square): 0.05 \mathrm{~mol}$

いものほど著しく上昇し， $150^{\circ} \mathrm{C} て ゙$ 加硫すると 24 $\mathrm{MPa}, 140^{\circ} \mathrm{C}$ では $26 \mathrm{MPa}, 130^{\circ} \mathrm{C}$ では $29 \mathrm{MPa} の$ 值を示した Fig. 6 )。また, 変形率 $200 \%$ のヒス テリシスループで, 構造変性 NRのヒステリシ スロスは，すべて著しく増加したが，加硫温度が 高くなるにつれ，減少する傾向を示した (Fig. 7 )。なお, $130^{\circ} \mathrm{C}$ の加硫では, 約 1.5 倍のヒステ リシスロスが得られた。構造変性 NRの圧縮永 久ひずみは， 130 および $140^{\circ} \mathrm{C} て ゙$ 加硫すると NR

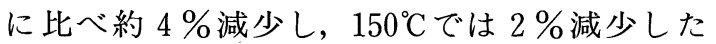

Table 3 Physical properties of carbon black-loaded NR vulcanizates modified with DMSO $^{\text {a) }}$

\begin{tabular}{lcccr}
\hline & \multirow{2}{*}{ Control } & \multicolumn{3}{c}{ Vulcanization temp. $\left({ }^{\circ} \mathrm{C}\right)$} \\
\cline { 2 - 5 } & & 130 & 140 & 150 \\
\hline Vulcanization time (min) $^{\text {b) }}$ & 24 & 29 & 16 & 9 \\
Compression set (\%) ${ }^{\mathrm{c})}$ & 32 & 28 & 28 & 30 \\
\hline
\end{tabular}

a) Amount of modifier : $0.01 \mathrm{~mol}$.

b) Torque100.

c) Condition : $22 \mathrm{~h}$ at $70^{\circ} \mathrm{C}$.

Table 4 Physical properties of carbon black-loaded NR vulcanizates modified with DMSO.

\begin{tabular}{lcccc}
\hline & \multirow{2}{*}{ Control } & \multicolumn{3}{c}{ DMSO (mol) } \\
\cline { 3 - 5 } & & 0.01 & 0.03 & 0.05 \\
\hline Vulcanization time (min) $^{\text {a) }}$ & 32 & 29 & 23 & 18 \\
Compression set $(\%)^{\text {b) }}$ & 32 & 33 & 38 & 41 \\
\hline
\end{tabular}

a) Torque 100 .

b) Condition : $22 \mathrm{~h}$ at $70^{\circ} \mathrm{C}$.

(Table 3 ).

加硫温度が低下するにつれヒステリシスロスが 増加し，圧縮永久Uずみは減少する傾向を示し た。また，DMSO はNRに対し，低い加硫温度 で容易に減衰性の付与を可能とすることが明らか となった。

3.3.2 DMSO の添加量による影響 添加量を $0.01 ， 0.03$ および $0.05 \mathrm{~mol}$ と増量したところ, 添加量の増加に伴いヒステリシスロスも増加の傾 向を示し，また圧縮永久ひずみ率も増加する傾向 を示した(Fig. 8) (Table 4). しかも， $0.05 \mathrm{~mol}$ 添加すると, 表面に未反応の DMSO がブリード していたことから，添加量は $0.05 \mathrm{~mol}$ 以下がよ く,できうれば $0.01 \mathrm{~mol}$ 以下が最適であろう。

また， $0.001 ， 0.005$ および $0.01 \mathrm{~mol}$ 添加する と, 添加量に比例して加硫速度が著しく促進され た.

キュラスト T 100 で加硫したゴムの応力ーひず み挙動において, 構造変性 $\mathrm{NR} の \mathrm{E}_{\mathrm{B}}$ は, 添加量 に関係なく少し上昇した. $0.001 \mathrm{~mol}$ 添加では, $\mathrm{T}_{\mathrm{B}}$ 值は $\mathrm{NR}$ とほぼ同じであるが，0.005 および $0.01 \mathrm{~mol}$ と増量すると, 著しく上昇した。また, 変形率 $200 \%$ のヒステリシスループでは， 0.001 mol 添加すると, NR とほぼ同じ值を示したが, $0.005 \mathrm{~mol}$ では NRの約 1.3 倍のヒステリシスロ 


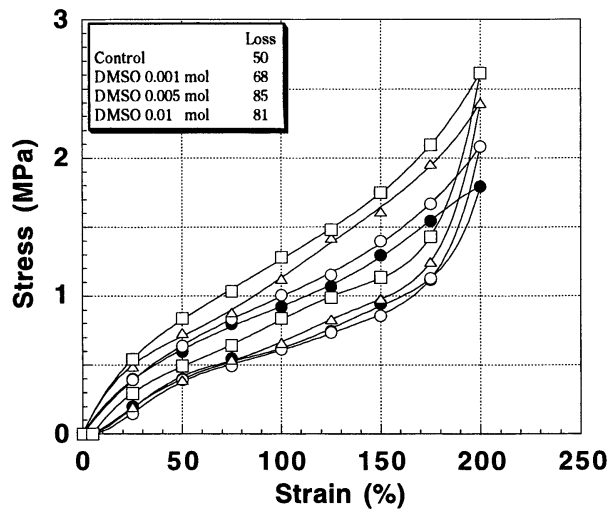

Fig. 9 Hysteresis loops of carbon blackloaded NR vulcanizates modified with DMSO.

(O) : Control, (O) : 0.001mol, $(\triangle)$ : $0.005 \mathrm{~mol}, \quad(\square): 0.01 \mathrm{~mol}$

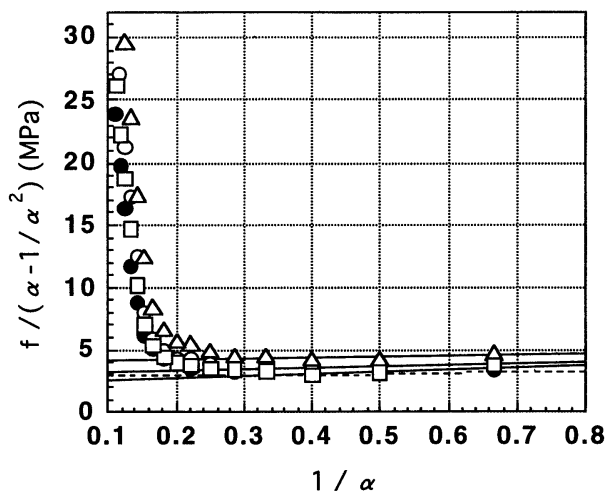

Fig. 10 The Mooney-Rivlin plot of modified NR vulcanzates by pure gum compound.

(O) : Control, (O) : DMSO, ( $\triangle)$ : TMSO, ( $\square):$ TMSN

スが得られた。しかし，更に増量し $0.01 \mathrm{~mol}$ と すると，口ス值は低下した(Fig. 9$)$. 構造変性 NR の圧縮永久Uずみは添加量にかかわらず，す べて減少した. 特に $0.005 \mathrm{~mol}$ 添加したとき， 6 \%減少した (Table 5 ). 添加量が増加するに伴 い， $\mathrm{T}_{\mathrm{B}}$ およびヒステリシスロスは増加するが, $0.01 \mathrm{~mol}$ 添加すると， $0.005 \mathrm{~mol}$ 添加した場合よ りも若干ヒステリシスロスが低下し，圧縮永久U ずみが増加した。したがって, 最適添加量は $0.005 \mathrm{~mol}$ であろう。また，最適添加量である $0.005 \mathrm{~mol}$ を質量で表すと $0.4 \mathrm{~g}$ であり，NRに
Table 5 Physical properties of carbon black-loaded NR vulcanizates modified with DMSO.

\begin{tabular}{lcccc}
\hline & \multirow{2}{*}{ Control } & \multicolumn{3}{c}{ DMSO (mol) } \\
\cline { 3 - 5 } & & 0.001 & 0.005 & 0.01 \\
\hline Vulcanization time (min) ${ }^{\text {a) }}$ & 32 & 29 & 23 & 18 \\
Compression set $(\%)^{\text {b) }}$ & 32 & 28 & 26 & 29 \\
\hline
\end{tabular}

a) Torque 100 .

b) Condition : $22 \mathrm{~h}$ at $70^{\circ} \mathrm{C}$.

Tabale $6 \quad \mathrm{C}_{1}$ and $\mathrm{C}_{2}$ of modified $\mathrm{NR}$ vulcanizates by the Mooney-Rivlin plot.

\begin{tabular}{lcc}
\hline & $\mathrm{C}_{1}$ & $\mathrm{C}_{2}$ \\
\hline NR & 1.41 & 0.39 \\
DMSO & 1.52 & 0.70 \\
TMSO & 2.03 & 0.44 \\
TMSN & 1.29 & 0.86 \\
\hline
\end{tabular}

対して $0.8 \mathrm{phr}$ と非常に少量の添加であるにもか かわらず，ヒステリシスロスが著しく増加したこ とから，その優れた活性も示唆された。

\section{4 ムーニー・リブリン式による構造変性 NR の解析}

ゴムの減衰評価法の一つとして, 純ゴム配合に おける構造変性 NR 加硫物のムーニー・リブリン プロットが挙げられる(Fig.10)。これより算出し た $\mathrm{C}_{1}$ および $\mathrm{C}_{2}$ の值を Table 6 に示す. $\mathrm{C}_{1}$ は, ゴム内部の化学網目に依存するパラメーターであ ク, 化学網目が多いゴムほどこの值は増加す る ${ }^{4)} \mathrm{C}_{2}$ はゴム内部の粘性に依存するパラメータ 一であり，粘性の高いゴムほどこの值は増加す $ろ^{5-7)}$. 構造変性 NR は, $\mathrm{TMSN}+\mathrm{NR}<$ $\mathrm{DMSO}+\mathrm{NR}<\mathrm{TMSO}+\mathrm{NR}$ の順に $\mathrm{C}_{1}$ の值が上 昇しており，膨潤試験による網目鎖密度の傾向と 一致した。また， $\mathrm{C}_{2}$ では，構造変性 NRのすべ てがNRの 0.39 よりも高い值を示した．異性化 効率が最も優れていた TMSN を添加した NRの 值が 0.86 と最も高く, TMSO を添加した NR は少し高い程度であった。また，DMSOを添加 した NR は，他の変性 NRの中間值である 0.70 を示したところから，異性化率とムーニー・リブ リンプロットの $\mathrm{C}_{2}$ との間には密接な関係がある と考えられ，異性化剤を用いて構造変性した NR は，化学網目の増加に加之て，分子鎖の絡み合い 


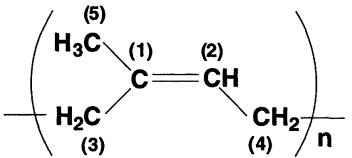

Fig. 11 The structural formula.

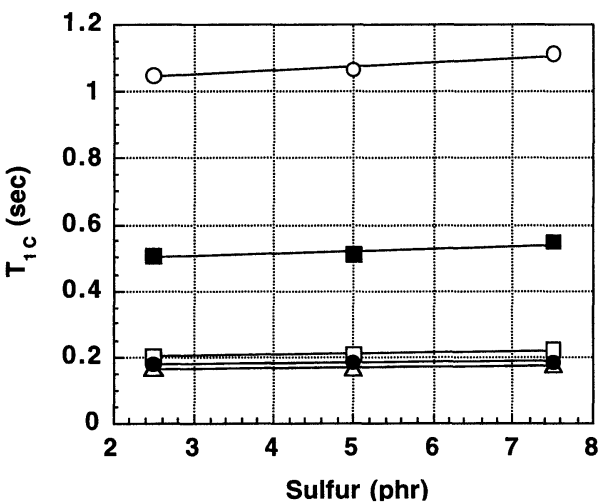

Fig. 12 Spin-lattice relaxation time $\left(T_{1 c}\right)$ of native NR vulcanizates by differing crosslinking density.

(O) : C(1) position shown in Fig.3, ( $\square): C$ $(2),(\triangle): C(3),(\bigcirc): C(4),(\square): C(5)$

および分子鎖間の相互作用による擬似網目のよう な非化学網目的な要素が関与していることが示唆 された ${ }^{8-12)}$.

\section{5 固体 ${ }^{13} \mathrm{C} N M R$ 測定による構造変性 NR の解析}

\subsection{1 構造変性 NR のスピンー格子緩和時間}

$\left(T_{1 c}\right)$ Inversion recovery 法による未変性 NR の $\mathrm{T}_{1 \mathrm{C}}$ は，炭素の種類によって異なり，4級炭 素 C (1) およびメチル基炭素 C ( 5 ) が特に長い值 を示す(Fig.11)。C (1) は直接結合している水素 がないため, C ( 5 ) は速い内部回転のためにその 緩和が長くなっているものと考えられてい $る^{13-14)}$. 架橋密度と $\mathrm{T}_{1 \mathrm{c}}$ との関係については, いろいろ報告されているが15-17)，一般的な定説 はなく得られる生成物によって異なった結果を示 している。未変性 NR は網目鎖密度が増加する のに伴い $\mathrm{T}_{1 \mathrm{C}}$ は長くなる傾向が得られた (Fig. 12).これは，硫黄の量に比例して網目鎖密度は 増加し，分子鎖の運動が抑制されることで，分子 内の炭素の分子運動性が低下したためだと考えら れる.しかし, 網目鎖密度が高いにもかかわら ず，構造変性 NR のほぼすべての炭素の $\mathrm{T}_{1 \mathrm{c}}$ が

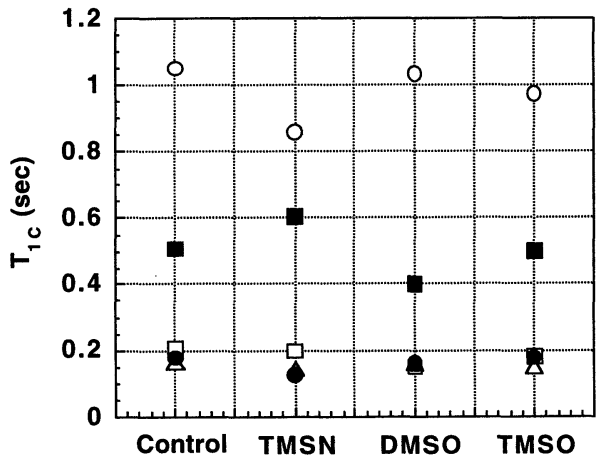

Fig. 13 Spin-lattice relaxation time $\left(T_{1 C}\right)$ of modified NR vulcanizates by differing crosslinking density.

(O) : C(1) position shown in Fig.3, ( $\square): \mathrm{C}$ $(2),(\triangle): C(3), \quad(\mathbf{O}): C(4), \quad(\square): C(5)$

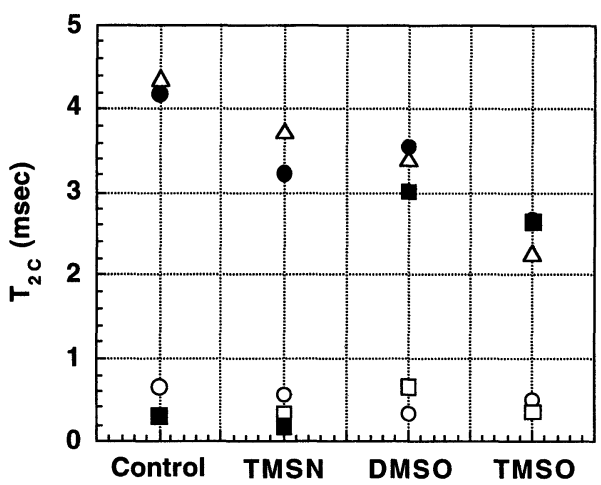

Fig. 14 Spin-spin relaxation time $\left(\mathrm{T}_{2 \mathrm{c}}\right)$ of modified NR vulcanizates by differing crosslinking density.

(O) : C (1) position shown in Fig.3, ( $\square): C$ $(2),(\triangle): C(3),(\bigcirc): C(4),(\square): C(5)$

短くなっていることから, 構造変性 NR は未変 性のものよりも分子鎖の運動性が増しており，分 子鎖の絡み合いおよび分子鎖間の弱い相互作用に よる擬似網目が，化学網目よりも優位を占めてい ることが示唆される (Fig.13).

\subsection{2 構造変性 NR のスピンースピン緩和時間} ( $\mathrm{T}_{2 \mathrm{c}}$ ) CPMG (Carr-Purcell Meiboom-Gill)法

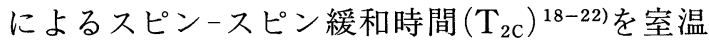
で測定し, Fig.14 に示す。構造変性 NR は, $\mathrm{TMSN}+\mathrm{NR}, \mathrm{DMSO}+\mathrm{NR}, \mathrm{TMSO}+\mathrm{NR}$ の順 に, 緩和の長い $\mathrm{C}(3,4)$ の $\mathrm{T}_{2 \mathrm{C}}$ が緩和の短い $\mathrm{C}$ $(1,2)$ の $\mathrm{T}_{2 \mathrm{C}}$ に収束しており，膨潤試験による 網目鎖密度の傾向と一致する.スルホンを添加し 
た $\mathrm{NR} の \mathrm{~T}_{2 \mathrm{c}}$ は, $\mathrm{C}(3,4)$ で少し短く, スルホ キシドを添加したNRもスルホンと同じ傾向を 示すが, $\mathrm{C}(5)$ は著しく長くなる. 緩和時間は未 変性および構造変性 NR では異なることから， スルホンはほぼ完全に異性化反応を起こすのに対 し，スルホキシドは異性化反応が不完全であると 考えられる。

\section{4. 結論}

NRにDMSO，TMSO およびTMSN などの スルホキシドおよびスルホンを反応させると， ト ランス異性化反応が進行することが明らかとなっ た. TMSN は，効率良く異性化反応を起こす が，DMSO および TMSO は，TMSN と比較し て異性化効率が少し低い.

NRに異性化による構造変性を起こさせると， 著しくヒステリシスロスが増加し，圧縮永久ひず み率も低下した．特にDMSO は，わずか 0.8 phrの添加で著しく減衰性を向上させ，低い加硫 温度でも高い減衰性を保つ実用性に優れた異性化 剂であることが明らかとなった。また，スルホキ シドおよびスルホンの添加による NRの異性化 は, 従来ゴム工業で定説となっていたヒステリシ スロスが増加するとともに圧縮永久ひずみも増加 するという解決が困難とされていた性質を打開 し，ヒステリシスロスは増加するが, 圧縮永久ひ ずみは減少するという二律背反性を切り開くこと が可能となった。

加硫ゴムの構造は, 化学的な一次網目および物 理的な二次網目から成り立っているが, 構造変性 NRは，未変性 NRよりも網目鎖密度が高いに もかかわらず，七ステリシスロスの著しい増加， ムーニー・リブリンプロットの $\mathrm{C}_{2}$ の上昇, 固 体 ${ }^{13} \mathrm{C}$ NMR 測定によるスピンー格子緩和時間 $\left(\mathrm{T}_{1 \mathrm{c}}\right)$ およびスピンースピン緩和時間 $\left(\mathrm{T}_{2 \mathrm{C}}\right)$ の収束 などを示すことから考えると，その高次構造は，
硫黄架橋による化学網目の増加以上に, 分子鎖の 絡み合いおよび分子鎖間の相互作用による擬似網 目が優位を占め，そのために粘性流動抵抗が著し く増加していると考えられる。

【付記】本研究結果の一部は, 日本ゴム協会主催 第 10 回エラストマー討論会(はあといん乃木坂 1997 年 12 月 $4-5$ 日)にて発表したものである.

\section{参 考 文 献}

1 ）藤田英夫：日ゴム協誌，52，695(1979)

2 ) 井本 稔：日ゴム協誌，32，110(1973)

3) 村上謙吉: 東北大学非水溶液化学研究所報告, 21 , 13(1971)

4 ）小野勝道：ゴム工業便覧〈第四版〉，1228(1994)

5 ) 岡本 弘, 稲垣慎二, 古川淳二：日ゴム協誌, 50, 338 (1977)

6 ）稲垣慎二, 尾之内千夫, 岡本 弘, 古川淳二：日ゴム 協誌，52，780(1979)

7 ) 岡本 弘, 稲垣慎二, 古川淳二：日ゴム協誌，53, 43(1980)

8 ）古川淳二：日ゴム協誌， 55，557(1982)

9 ）古川淳二 : 表面, 17, 739(1979)

10）古川淳二：表面，18，125(1980)

11）古川淳二：日本接着協会誌， 16，65(1980)

12）古川淳二：色材, 58, 264 (1985)

13）畑田耕一：日ゴム協誌，54，497(1981)

14) Schaefer, J.: Macromolecules, 5, 429(1972)

15) Rowland, T.J., Labun, L.C.: Macromolecules, 11, 466 (1978)

16) Munic, G.C., Jiri Jonas: J. Polymer Sci., Polym. Chem. Ed., 18, 1061 (1980)

17) Shi, J.F., Dickinson, L.C., MacKnight, W.J.: Macromolecules, 26, 5908(1993)

18）藤本邦彦，西，敏夫：日ゴム協誌，45，654 (1972)

19) Krejsa, M.R., Koenig, J.L. : Rubber Chem. Technol., 65, 961 (1992)

20) Munic, G.C., Jiri Jonas: J. Polymer Sci., Polym. Chem. Ed., 18, 1067 (1980)

21）畑田耕一：日ゴム協誌，54，493(1981)

22）西 敏夫：ゴム工業便覧〈第四版〉，1239(1994) 